\title{
Glucose utilization in the horse
}

\author{
BY E. J. H. FORD AND JOAN EVANS \\ Department of Veterinary Clinical Studies, University of Liverpool, Leahurst, \\ Neston, S. Wirral L64 7TE
}

(Received 8 July 1981 - Accepted 15 February 1982)

\begin{abstract}
1. Total entry, irreversible loss and recycling rates of glucose were measured in four non-pregnant female Shetland ponies before and after a $24 \mathrm{~h}$ fast by the continuous intravenous infusion of a mixture of $\left[\mathrm{U}-{ }^{14} \mathrm{C}\right] \mathrm{glucose}$ and $\left[2-^{3} \mathrm{H}\right]$ glucose.

2. The post-fasting fall in the concentration of glucose and the rise in the concentration of ketones in plasma were not significant.

3. After fasting, the total entry rate fell from $1.44 \pm 0.11(n)$ to $1 \cdot 19 \pm 0.12 \mathrm{mg} / \mathrm{min}$ per $\mathrm{kg}$ body-weight $(P<0.01)$ and irreversible loss fell from $1.36 \pm 0.10(n)$ to $1.05 \pm 0.10 \mathrm{mg} / \mathrm{min}$ per $\mathrm{kg}$ body-weight $(P<0 \cdot 02)$. Recycling rate did not change significantly.

4. In one pony the intravenous infusion of glucose at rates of $0.52,1.0$ or $1.64 \mathrm{mg} / \mathrm{min}$ per $\mathrm{kg}$ body-weight had no appreciable effect on endogenous glucose production whereas in a second pony, similarly fed, total entry was depressed by $43 \%$ and irreversible loss by $54 \%$.

5. Irreversible loss of glucose in the horse is similar to that of many other species.
\end{abstract}

Utilization, entry, turnover, removal or flux, are terms used to describe the rate at which a metabolite enters or leaves the plasma pool when the concentration of the metabolite in the pool is steady. Isotope dilution techniques have been used to measure glucose utilization in single stomached species such as the rat (Feller et al. 1950), the dog (Steele et al. 1956) and man (Baker et al. 1954). In ruminants, which absorb only small quantities of glucose from the alimentary canal because most of the ingested carbohydrates are fermented in the rumen, entry or utilization rates have been measured by isotope-dilution methods by, for example, Annison \& White (1961), Bergman (1963), Ford (1963) and White et al. (1969).

The horse is a single-stomached herbivorous animal in which substantial fermentation is believed to occur in the caecum and large colon. Previous studies on glucose utilization in the horse have been made on animals fed on a variety of diets and fasted for various periods up to $7 \mathrm{~d}$. Evans (1971) used a single intravenous injection of [U-14 C]glucose, Ginochio \& Evans (1973) used a single injection of $\left[2-{ }^{3} \mathrm{H}\right] \mathrm{glucose}$, Anwar et al. (1976) used a single intravenous injection of a mixture of [U-14 $\mathrm{C}]$ glucose and glucose tritiated in various positions whilst Argenzio \& Hintz (1972) and Linzell et al. (1972) gave continuous intravenous infusions of $\left[\mathrm{U}-{ }^{14} \mathrm{C}\right]$ glucose. Because of these differences it is very difficult to compare the results obtained by the investigators who have used the horse and it is equally difficult to use their results to compare the utilization of glucose by the horse with that of ruminants or of other species which have a single stomach.

We wished to study the effect of a $24 \mathrm{~h}$ fast and of the infusion of a glucose load on various aspects of glucose metabolism in the horse and to compare our results in the fed animal with those obtained from investigations on other species. We chose to use a continuous intravenous infusion of $\left[\mathrm{U}^{-14} \mathrm{C}\right] \mathrm{glucose}$ and $\left[2{ }^{3} \mathrm{H}\right]$ glucose following the suggestion of White et al. (1969) that the use of the former label measures irreversible loss of glucose and the latter measures total entry rate because the tritium released from the metabolism of glucose labelled with this isotope is diluted in the body water pool and excreted rather than recycled. Recycling of glucose can then be calculated by difference so that we have been able to study the effect of a $24 \mathrm{~h}$ fast and of an infused glucose load on three different aspects of glucose metabolism. 
MATERIALS AND METHODS

Experimental animals. Four female Shetland ponies aged 3-4 years were housed in loose boxes on a straw bed, and given $3200 \mathrm{~g}$ chopped hay/d with free access to water. They were trained to stand in simple tubular stocks during the infusion procedure. Some experiments were carried out after a $24 \mathrm{~h}$ fast, during which time the ponies were bedded on wood shavings and deprived of hay but not water.

Experimental procedure. Before infusion a polythene cannula (o.d. approximately $2 \mathrm{~mm}$ ) was inserted into each jugular vein under local anaesthesia. The radioactive infusions were given by a peristaltic pump (Watson-Marlow flow inducer) into one of the jugular cannulas and each contained $160 \mu \mathrm{Ci}\left[2-{ }^{3} \mathrm{H}\right]$ glucose (TRK 361; Radiochemical Centre, Amersham, Bucks) and $160 \mu \mathrm{Ci}\left[\mathrm{U}-{ }^{14} \mathrm{C}\right] \mathrm{glucose}\left(\mathrm{CFB}_{2}\right.$; Radiochemical Centre) in buffered sodium chloride solution $(9 \mathrm{~g} / 1)$ at $\mathrm{pH} 7.0$ containing $0.4 \mathrm{~g}$ glucose $/ 1$. The infusion was given over approximately $4 \mathrm{~h}$ at $2 \mathrm{ml} / \mathrm{min}$. Each infusion was preceded by the rapid intravenous injection of a priming dose of $40 \mu \mathrm{Ci}\left[2{ }^{3} \mathrm{H}\right]$ glucose and $40 \mu \mathrm{Ci}\left[\mathrm{U}-{ }^{14} \mathrm{C}\right]$ glucose. In the experiments to investigate the utilization of an infused glucose load the $4 \mathrm{~h}$ primed infusion as described previously was immediately followed by a second $4 \mathrm{~h}$ infusion. This also contained $160 \mu \mathrm{Ci}\left[2-{ }^{3} \mathrm{H}\right]$ glucose and $160 \mu \mathrm{Ci}\left[\mathrm{U}-{ }^{14} \mathrm{C}\right]$ glucose and sufficient non-radioactive glucose to give infusion rates of glucose of approximately $0.5,1.0$ and $1.65 \mathrm{mg} / \mathrm{min}$ per $\mathrm{kg}$ body-weight.

During the last hour of each infusion between eight and ten blood samples were collected into heparin and sodium fluoride from the cannula on the opposite side of the neck to that through which the infusion was given. The plasma was removed by centrifugation and stored at $-20^{\circ}$ in polyethylene vials until analysis was carried out. During the experiments in which additional unlabelled glucose was infused samples of urine were collected with a Dowse catheter.

Chemical methods. The concentration of glucose in plasma and urine was measured by the enzymic method of Huggett \& Nixon (1957). The concentration of glucose in whole blood, in plasma and in washed erythrocytes was measured in a large number of samples collected from the ponies during the infusion periods and at other times. The concentration of glucose in erythrocytes was also calculated by using the concentrations in whole blood and plasma and the packed cell volume. The concentration of total ketone bodies in plasma was measured by a slight modification (Ford \& Boyd, 1960) of the method of Bakker \& White (1957). From plasma and infusion fluid glucose pentaacetate was prepared and recrystallized by the method of Jones (1965) in order to measure the specific radioactivity of ${ }^{3} \mathrm{H}$ - and ${ }^{14} \mathrm{C}$-labelled glucose. The pentaacetate was dissolved in toluene containing (/I) $4 \mathrm{~g}$ 2,5-diphenyl-oxazone (PPO) and $0.2 \mathrm{~g}$ 1,4-di-(5-phenyl-oxazolyl)-benzene (POPOP) and the radioactivity of the two labels was determined by the channels-ratio method of Hetenyi \& Reynolds (1967) in an automatic liquid-scintillation counter with external standard. The packed cell volume of blood samples was measured using a Hawksley microhaematocrit centrifuge.

\section{RESULTS}

The amount of glucose in erythrocytes ranged from 0 to $2.5 \mathrm{mmol} / \mathrm{l}$. In general the calculated concentration derived from measurements on whole blood and plasma was higher than that obtained directly from a suspension of washed erythrocytes but an individual animal would have a consistently high or low concentration by either method when sampled on different occasions. However, when the specific activity of glucose in plasma and whole blood was measured during the last hour of the infusions there was no detectable difference. For this reason all calculations of utilization rates have been based on the specific activity of glucose in plasma. 
Table 1. Effect of a $24 \mathrm{~h}$ fast on glucose concentration and kinetics in four female Shetland ponies and the significance of the changes

(Mean values with their standard errors)

\begin{tabular}{|c|c|c|c|c|}
\hline & Fed & Fasted & Fed & Fasted \\
\hline $\begin{array}{c}\text { Mean concentrations } \\
\text { in plasma }\end{array}$ & \multicolumn{2}{|c|}{$\begin{array}{l}\text { Glucose } \\
(\mathrm{mmol} / \mathrm{l})\end{array}$} & \multicolumn{2}{|c|}{$\begin{array}{l}\text { Ketones } \\
(\mu \mathrm{mol} / 1)\end{array}$} \\
\hline Total entry & \multicolumn{2}{|c|}{$\begin{array}{l}\mathrm{NS} \\
(\mathrm{mg} / \mathrm{min} \text { per kg body-wt) }\end{array}$} & \multicolumn{2}{|c|}{$\begin{array}{l}\text { NS } \\
(\mathrm{g} / \mathrm{d})\end{array}$} \\
\hline Irreversible loss & \multicolumn{2}{|c|}{$\begin{array}{c}1.44 \pm 0.11 \quad 1 \cdot 19 \pm 0.12 \\
P<0.01 \\
(\mathrm{mg} / \mathrm{min} \text { per kg body-wt) }\end{array}$} & \multicolumn{2}{|c|}{$\begin{array}{c}P<0.05 \\
(\mathrm{~g} / \mathrm{d})\end{array}$} \\
\hline \multirow[t]{2}{*}{ Recycling } & \multicolumn{2}{|c|}{$\begin{array}{c}P<0.02 \\
(\mathrm{mg} / \mathrm{min} \text { per kg body-wt })\end{array}$} & \multicolumn{2}{|c|}{$\begin{array}{c}P<0.01 \\
(\mathrm{~g} / \mathrm{d})\end{array}$} \\
\hline & $0.08 \pm 0.016$ & $0 \cdot 13 \pm 0.028$ & $21 \cdot 7 \pm 3 \cdot 2$ & $38 \cdot 0 \pm 5 \cdot 7$ \\
\hline
\end{tabular}

NS, not significant.

Table 1 gives the effect of a $24 \mathrm{~h}$ fast on the concentration of glucose and ketone bodies in plasma and on the total entry, irreversible loss and recycling rates of glucose in four ponies. The fall in the concentration of glucose, the increase in the concentration of ketone bodies and the increase in the rate of glucose recycling were not statistically significant whereas the decrease in total entry and irreversible loss were highly significant $(P<0.01$ and $P<0.02$ respectively). Results before and after fasting were compared by the $t$ test for paired data.

Table 2 shows the effect of the intravenous infusion of a glucose load on several aspects of glucose utilization. Although the aim was to test the effect of glucose loads of $0.5,1.0$ and $1.6 \mathrm{mg} / \mathrm{min}$ per $\mathrm{kg}$ body-weight the rates actually obtained, due to differences in infusion rate between experiments, were slightly different and are given in Table 2 . The experiments were carried out in two female ponies from each of which several urine samples were collected during the intravenous infusions. Results obtained from the infusion of a load greater than $1.7 \mathrm{mg} / \mathrm{min}$ per $\mathrm{kg}$ body-weight were discarded because glucose was found in the urine during these infusions.

In each experiment there was a marked increase in the concentration of glucose in plasma. The increase was greatest when the glucose load was greatest and in all experiments the increased concentration and lower specific activity were maintained as steady plateaux during the last hour or more of the period when the load was being infused.

If the infused glucose had no effect on the endogenous production of glucose the total entry rate during the infusion would be the entry rate without load plus the infused load. Any reduction must be due to inhibition of endogenous production by the infusion. For example, in Expt 1 a total entry of 2.08 (i.e. $1.56+0.52 \mathrm{mg} / \mathrm{min}$ per $\mathrm{kg}$ body-weight) would be expected if no depression had occurred whereas the measured rate was $1.97 \mathrm{mg} / \mathrm{min}$ per $\mathrm{kg}$ body-weight. Therefore the rate of inhibition was $0.11 \mathrm{mg} / \mathrm{min}$ per $\mathrm{kg}$ body-weight or $7 \%$ of the endogenous rate of $1.56 \mathrm{mg} / \mathrm{min}$ per $\mathrm{kg}$ body-weight. There was a marked difference between the two animals, as three experiments on pony 1 showed no net 


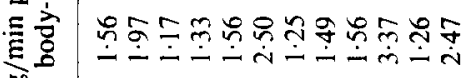

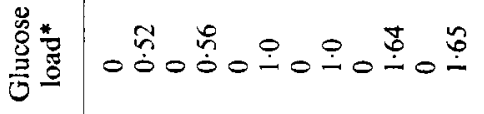


depression of entry or irreversible loss whereas the mean percentage depression in the three experiments on pony 2 was 43 for total entry and 54 for irreversible loss. The effect on recycling was negligible at the two lower rates of glucose infusion whereas infusion at the rate of $1.65 \mathrm{mg} / \mathrm{min}$ per $\mathrm{kg}$ body-weight depressed recycling in both ponies.

\section{DISCUSSION}

\section{Concentration of glucose in plasma}

It is not easy to compare our results with those of earlier work on horses (e.g. Stewart \& Holman, 1940; Alexander, 1955) because different rations and different methods of analysis were used. Whole blood rather than plasma was usually analysed and our preliminary experiments showed differences in the glucose content of erythrocytes of individual horses. However, there is broad agreement between our plasma content of approximately $5.6 \mathrm{mmol} / \mathrm{l}$ and Alexander's (1955) results for whole blood glucose of from 660 to $1000 \mathrm{mg} / 1$, mean values which he obtained from eight individuals during periods of 3-36 months. Similarly, Baetz \& Pearson (1972) found a mean plasma glucose concentration of $809 \pm 97$ $(n 8) \mathrm{mg} / \mathrm{l}$ in ponies fed twice daily on a pelleted compound ration containing $(\mathrm{g} / \mathrm{kg}) 120$ crude protein (nitrogen $\times 6.25$ ) and 200 fibre. There was no significant change during a $9 \mathrm{~d}$ fast. Most of the information in the literature indicates that the concentration of glucose in plasma or whole blood is higher than the corresponding values in ruminants.

In our experiments, fasting for $24 \mathrm{~h}$ produced a small but insignificant fall in the concentration of glucose in plasma. This is surprising in view of Alexander's (1955) demonstration that orally-administered glucose is rapidly absorbed into plasma, presumably from the small intestine, and because $24 \mathrm{~h}$ fasting would be expected to reduce considerably the amount of soluble carbohydrate in the stomach and small intestine. In Alexander's (1955) experiments, withholding of food for $24-28 \mathrm{~h}$ caused a fall in blood sugar concentration to the lower end of the normal range and a further $24 \mathrm{~h}$ starvation was accompanied by a rise in concentration. Evans (1971) fasted five horses for $72 \mathrm{~h}$ and found that there was a $20 \%$ reduction in the mean plasma glucose concentration. Ginochio \& Evans (1973) found no significant fall in the plasma glucose concentration of Shetland ponies during a $72 \mathrm{~h}$ fast and suggested that there may be a difference between the glucose metabolism of ponies and horses. Anwar $e t$ al. (1976) found that mean glucose concentration was lower in ponies fasted for $72 \mathrm{~h}$ but not significantly lower. On the other hand, Argenzio \& Hintz (1972) found a significant fall in the concentration of glucose in the plasma of ponies fasted for $72 \mathrm{~h}$.

\section{Comparison of irreversible loss of glucose in the horse and other species}

In many of the earlier measurements of entry rates of glucose, continuous infusions of $\left[\mathrm{U}-{ }^{14} \mathrm{C}\right]$ glucose were used. White et al. (1969) have suggested that, because of the recycling of glucose- $C$, this method measures irreversible loss or the rate at which glucose- $C$ leaves the sampled plasma never to return to that compartment. Measurements of rates of glucose entry or utilization with continuously-infused $\left[\mathrm{U}-{ }^{14} \mathrm{C}\right]$ glucose have been made in many species and it is interesting to compare the rates in different species. For purposes of comparison the results have been converted to $\mathrm{mg}$ glucose $/ \mathrm{min}$ per $\mathrm{kg}$ body-weight ${ }^{0.75}$. Examples of rates obtained in other species are: rat 5.5 (Depocas, 1959); rabbit 4-0 (Dunn et al. 1976); dog 6.7 (Searle et al. 1956), 6.0 (Steele et al 1956); sheep 3.8 (Bergman, 1963), 4.0 (Ford, 1963); reindeer 1.7-4.3 (Luick et al. 1973); cattle 8.2 (Leng, 1970).

The rate of 4.76 for fed non-pregnant non-lactating ponies obtained in the present experiment is of the same order as that of most other species except cattle and perhaps the dog. This similarity is somewhat surprising in view of the differences in the anatomy of the gastro-intestinal tracts of the various species. 


\section{Comparison of total entry rate of glucose in the horse and other species}

Judson \& Leng (1972) concluded that $\left[2-{ }^{3} \mathrm{H}\right]$ glucose was a useful tool for measuring total entry rate and that combined infusions of $\left[2-{ }^{3} \mathrm{H}\right]$ glucose and $\left[\mathrm{U}-{ }^{14} \mathrm{C}\right] \mathrm{glucose}$ can be used to measure total entry and irreversible loss of glucose at the same time. The difference between the two measurements indicates the rate at which $\mathrm{C}$ derived from glucose is recycled, i.e. incorporated into the glucose molecule during gluconeogenesis.

In most species there have been fewer measurements of total entry rate than of irreversible loss because tritiated glucose has been used less frequently than ${ }^{14} \mathrm{C}$-labelled glucose although some investigators have calculated so-called 'entry rates' from the early components of the curve obtained by plotting plasma radioactivity $v$. time after a single intravenous injection of [U- $\left.{ }^{14} \mathrm{C}\right] \mathrm{glucose}$. A rate of $4.2 \mathrm{mg} / \mathrm{min}$ per $\mathrm{kg}$ body-weight was found by Dunn et al. (1976) in rabbits, $8 \mathrm{mg} / \mathrm{min}$ per $\mathrm{kg}$ body-weight by Flecknell et al. (1980) in young pigs, and $4.0 \mathrm{mg} / \mathrm{min}$ per $\mathrm{kg}$ body-weight by Luick et al. (1973) in reindeer. Little work with tritiated glucose has been done in cattle but in sheep a total entry rate of $2.0 \mathrm{mg} / \mathrm{min}$ per kg body-weight was obtained by Judson \& Leng (1972), $1.44 \mathrm{mg} / \mathrm{min}$ per kg body-weight by Ranaweera \& Ford (1976), $2.8 \mathrm{mg} / \mathrm{min}$ per $\mathrm{kg}$ body-weight in pregnant sheep by Ford et al. (1979) and $1.24 \mathrm{mg} / \mathrm{min}$ per $\mathrm{kg}$ body-weight by Wilson et al. (1981). The present rate of $1.44 \mathrm{mg} / \mathrm{min}$ per $\mathrm{kg}$ body-weight suggests that the horse is similar to the sheep in this respect.

\section{Total entry and irreversible loss of glucose in the horse}

Evans (1971) used single injections of [U-14C]glucose in mares fed on unspecified amounts of a pelleted ration and calculated a total entry rate of 2.36 which fell to 1.98 after a $72 \mathrm{~h}$ fast but not significantly so. Irreversible loss was 1.34 which fell significantly $(P<0.025)$ to $0.65 \mathrm{mg} / \mathrm{min}$ per $\mathrm{kg}$ body-weight on fasting.

Argenzio \& Hintz (1972) used primed infusions of $\left[\mathrm{U}-{ }^{14} \mathrm{C}\right]$ glucose in Shetland ponies fed to constant weight and obtained a mean irreversible loss rate of $1.6 \mathrm{mg} / \mathrm{min}$ per $\mathrm{kg}$ body-weight in four ponies. This fell significantly $(P<0.01)$ to $0.8 \mathrm{mg} / \mathrm{min}$ per $\mathrm{kg}$ body-weight after a $72 \mathrm{~h}$ fast. Linzell et al. (1972) obtained an irreversible loss of $2 \mathrm{mg} / \mathrm{min}$ per $\mathrm{kg}$ body-weight in two lactating pony mares. Ginochio \& Evans (1973) gave unlimited amounts of a pelleted ration to Shetland ponies, used single injections of $\left[2{ }^{3} \mathrm{H}\right]$ glucose and obtained a total entry rate of $1.5 \mathrm{mg} / \mathrm{min}$ per $\mathrm{kg}$ body-weight.

The results obtained in the present experiments are of the same order as those quoted previously. However, Anwar et al. (1976) gave unlimited amounts of hay to ponies and used single injections of a mixture of $\left[\mathrm{U}^{14} \mathrm{C}\right]$ glucose and $\left[2,3-{ }^{3} \mathrm{H}\right]$ glucose or $\left[6-{ }^{3} \mathrm{H}\right]$ glucose. They obtained an irreversible loss of $1.5 \mathrm{mg} / \mathrm{min}$ per $\mathrm{kg}$ body-weight which decreased but not significantly so after a $72 \mathrm{~h}$ fast. They calculated a recycling rate of $16 \%$.

In spite of the difference in diets fed by various investigators there is broad agreement concerning the magnitude of both total entry rate and irreversible loss although the recycling rate of $5.5 \%$ in the present experiments was less than that of Anwar et al. (1976).

The magnitude of glucose production and utilization by the horse suggests that this aspect of its metabolism resembles that of ruminants more closely than that of other single-stomached animals. The relatively slight effect of a $24 \mathrm{~h}$ and even $72 \mathrm{~h}$ fast suggests that the contribution of glucose absorption by the small intestine may be small or that uptake of glucose from the portal blood by the liver is rapid. If gluconeogenesis is the main source of the glucose utilized by the tissues of the horse, this may well increase during a fast and minimize the effect of reduced intestinal production and absorption. 


\section{Effect of an intravenous glucose load}

There is no published information on experiments on the horse but Anison \& White (1961), West \& Passey (1967) and Thompson et al. (1975) have described experiments in sheep and cattle.

Annison \& White (1961) found almost complete suppression of endogenous utilization (irreversible loss) in five sheep under glucose load, whilst West \& Passey (1967) obtained 64 and $88 \%$ suppression in two sheep. In seven trials on four lactating cows, Thompson et al. (1975) obtained a mean decrease in endogenous production of $68 \%$. Table 2 shows that pony no. 2 responded to glucose loading in a similar manner to ruminants whereas pony no. 1 was much more resistant to the effect of glucose loads of three different magnitudes.

The authors are grateful to F. K. Johns for the care of the ponies, and to the Horserace Betting Levy Board for financial support.

\section{REFERENCES}

Alexander, F. (1955). Q. Jl exp. Physiol. 40, 24.

Annison, E. F. \& White, R. R. (1961). Biochem. J. 80, 162.

Anwar, M. S., Chapman, T. E. \& Gronwall, R. (1976). Am. J. Physiol. 230, 138.

Argenzio, R. A. \& Hintz, H. F. (1972). J. Nutr. 102, 879.

Baetz, A. L. \& Pearson, J. E. (1972). Am. J. vet. Res. 33, 1941

Baker, N., Shreeve, W. W., Shipley, R. A., Incefy, G. E. \& Miller, M. (1954). J. biol. Chem. 211, 575.

Bakker, N. \& White, R. R. (1957). N.Z. Jl Sci. Tech. 38B, 1001.

Bergman, E. N. (1963). Am. J. Physiol. 204, 147.

Depocas, F. (1959). Can. J. Biochem. Physiol. 37, 285.

Dunn, A., Katz, J., Golden, S. \& Chenoweth, M. (1976). Am. J. Physiol. 230, 1159.

Evans, J. W. (1971). J. Anim. Sci. 33, 1001.

Feller, D. D., Strisower, E. H. \& Chaikoff, I. L. (1950). J. biol. Chem. 187, 571.

Flecknell, P. A., Wootlan, R. \& John, M. (1980). Br. J. Nutr. 44, 193.

Ford, E. J. H. (1963). Biochem. J. 88, 427.

Ford, E. J. H. \& Boyd, J. W. (1960). Res. vet. Sci. 1, 232.

Ford, E. J. H., Samad, A. R. \& Purcell, H. (1979). J. agric. Sci., Camb. 92, 323.

Ginochio, R. J. \& Evans, J. W. (1973). J. Anim. Sci. 37, 484.

Hetenyi, G. \& Reynolds, J. (1967). Int. J. app. Rad. Isot. 18, 331.

Huggett, A. St G. \& Nixon, D. A. (1957). Lancet ii, 368.

Jones, G. B. (1965). Analyt. Biochem. 12, 249.

Judson, G. J. \& Leng, R. A. (1972). Aust. J. biol. Sci. 25, 1313.

Leng, R. A. (1970). Adv. vet. Sci. 14, 209.

Linzell, J. L., Annison, E. F., Bickerstaffe, R. \& Jeffcott, L. B. (1972). Proc. Nutr. Soc. 31, 72 A.

Luick, J. R., Person, S. J., Cameron, R. D. \& White, R. G. (1973). Br. J. Nutr. 29, 245.

Ranaweera, A. \& Ford, E. J. H. (1976). J. agric. Sci., Camb. 87, 417.

Searle, G. L., Strisower, E. H. \& Chaikoff, I. L. (1956). Am. J. Physiol. 185, 589.

Steele, R., Wall, J. S. de Bodo, R. C. \& Altszuler, N. (1956). Am. J. Physiol. 187, 15.

Stewart, J. \& Holman, H. H. (1940). Vet. Rec. 52, 157.

Thompson, J. R., Weiser, G., Seto, K. \& Black, A. L. (1975). J. Dairy Sci. 58, 362.

West, C. E. \& Passey, R. F. (1967). Biochem. J. 102, 58.

White, R. G., Steele, J. W., Leng, R. A. \& Luick, J. R. (1969). Biochem. J. 114, 203.

Wilson, S., MacRae, J. C. \& Buttery, P. J. (1981). Res. vet. Sci. 30, 205. 